\title{
Clinical-histopathological Features of Paratesticular Masses and Factors Affecting Survival: Single Center Experience
}

\section{Paratestiküler Kitlelerin Klinik-histopatolojik Özellikleri ve Sağkalıma Etki Eden Faktörler: Tek Merkez Deneyimi}

\author{
(i) İsmail SELVİ1, id Halil BAŞAR²
}

${ }^{1}$ Karabük University Training and Research Hospital, Clinic of Urology, Karabük, Turkey

2University of Health Sciences, Dr. Abdurrahman Yurtaslan Ankara Oncology Training and Research Hospital, Clinic of Urology, Ankara,

Turkey

\section{ABSTRACT}

Objective: As paratesticular masses constitute $2-3 \%$ of all scrotal and inguinal masses, published cases in the literature are limited. We aimed to present our experiences of nine cases which we have treated and followed up in our department.

Methods: Between January 2013 and February 2017, we retrospectively analyzed the data of nine patients with paratesticular mass in our department.

Results: Seven $(77.8 \%)$ patients presented with scrotal mass or swelling, while two $(22.2 \%)$ patients had swelling in the inguinal region. Histological types of malign tumors were rhabdomyosarcoma [(RMS), 2 cases, 22.3\%)], liposarcoma [(LPS), 1 case, 11.1\%)], leiomyosarcoma [(LMS), 1 case, 11.1\%)] and malignant fibrous histiocytoma [(MFH), 1 case, $11.1 \%)]$. Bening tumors were fibroma ( 1 case, $11.1 \%$ ), adenomatoid tumor (1 case, $11.1 \%$ ), cystadenoma ( 1 case, $11.1 \%)$ and inflammatory myofibroblastic tumor (1 case, $11.1 \%$ ). During median 23.5 (4-62) months of follow-up of paratesticular sarcomas, the rates of recurrence-free and progressionfree survival were $60 \%$, overall survival rate was $60 \%$. LMS and MFH had poor prognosis. No recurrence or progression was observed in the follow-up of LPS and RMS. Among them, LPS had the best prognosis. The disease-free survival was $100 \%$ at the median 49 (36-64) months follow-up of four benign masses without any

\section{ÖZ}

Amaç: Paratestiküler kitleler, tüm skrotal ve inguinal kitlelerin \%2-3 gibi oldukça az bir kısmını oluşturduğundan, literatürde bildirilmiş olgular kısıtlıdır. Kliniğimizde paratestiküler kitle nedeniyle takip ve tedavisini gerçekleştirdiğimiz dokuz olguya ait deneyimlerimizi sunmayı amaçladık.

Yöntemler: Ocak 2013-Şubat 2017 arasında, kliniğimizde paratestiküler kitle nedeniyle takip ve tedavi ettiğimiz 3-72 yaş arasındaki dokuz olgunun verilerini, postoperatif takip sürecindeki bulgularını retrospektif olarak inceledik.

Bulgular: Yedi $(\% 77,8)$ olgu skrotal kitle, şişlik yakınması ile başvururken, iki $(\% 22,2)$ hasta inguinal bölgede şişlik nedeniyle başvurdu. Patolojik tanısı malign gelen tümörlerin histolojik tipleri rabdomyosarkom [(RMS), 2 olgu, \%22,3)], liposarkom [(LPS), 1 olgu, \%11,1)], [leiomyosarkom (LMS), 1 olgu,\%11,1)] ve malign fibröz histiyostom [(MFH), 1 olgu, \%11,1)] idi. Benign patolojili tümörler ise, fibroma (1 olgu, \%11,1), adenomatoid tümör (1 olgu,\%11,1), kistadenom (1 olgu, \%11,1) ve enflamatuvar miyofibroblastik tümör (1 olgu, \%11,1) olarak saptandı. Beş sarkom olgusunun medyan 23,5 (4-62) aylık takibinde nükssüz ve progresyonsuz sağkalım oranı $\% 60$ iken, genel sağkalım oranı $\% 60$ idi. Bu beş olgudan en kötü prognozlu olanlar LMS ve MFH'idi. LPS ile RMS olgularının takibinde nüks ve progresyon gözlenmezken, en iyi prognoz LPS'ye aitti. Adjuvan tedavi gereksinimi olmayan

Address for Correspondence: İsmail SELVi, Karabük University Training and Research Hospital, Clinic of Urology, Karabük, Turkey

E-mail: ismselvi33@hotmail.com ORCID ID: orcid.org/0000-0003-3578-0732

Cite this article as: Selvi I, Başar H. Clinical-histopathological Features of Paratesticular Masses and Factors Affecting Survival: Single Center Experience. Bezmialem Science 2020;8(1):1-7. 
need for adjuvant treatment. According to FNCLCC Classification, times of local recurrence-free survival and overall survival in grade II sarcomas were significantly higher than those with grade III $(\mathrm{p}=0.039)$.

Conclusion: It is difficult to differentiate clinically benign paratesticular masses from sarcomas. LPS has better prognosis and high-grade sarcomas have poor prognosis. If adjuvant treatments are not added, local recurrence or progression may be observed in a short time.

Keywords: Benign paratesticular masses, FNCLCC grading system, local recurrence free survival, overall survival, paratesticular sarcomas dört benign kitlenin median 49 (36-64) aylık takibinde hastalıksız sağkalım \%100'dü. FNCLCC sınıflandırması'na göre derece 2 sarkomlarda lokal nükssüz sağkalım ve genel sağkalım süreleri, derece 3'e göre anlamlı olarak daha fazla saptandı $(\mathrm{p}=0,039)$.

Sonuç: Benign paratestiküler kitleleri, sarkomlardan klinik olarak ayırt etmek zordur. Paratestiküler sarkomlarda histolojik alt tipler içerisinde LPS daha iyi prognoza sahiptir. Yüksek dereceli sarkomların prognozu daha kötüdür. Adjuvan tedaviler eklenmezse, kısa sürede lokal nüks veya progresyon gözlenebilmektedir.

Anahtar Sözcükler: Benign paratestiküler kitleler, FNCLCC derecelendirme sistemi, genel sağkalım, lokal nükssüz sağkalım, paratestiküler sarkomlar

\section{Introduction}

Paratesticular area consists of embryological remains such as epididymis, spermatic cord, tunica vaginalis, appendix testis, and inguinal canal and supporting tissues (1). Although tumors originating from this region are rare, they have a wide distribution in terms of pathological diversity due to the different anatomical structures they contain (2). Paratesticular masses account for $2-3 \%$ of all scrotal masses $(1,3)$. Although the rate of malignancy is lower than intratesticular masses, it is difficult to distinguish precisely with clinical findings. When the suspicion of malignancy cannot be ruled out in benign masses, radical orchiectomy is often performed (3). On the other hand, malignant masses can be interpreted as benign inguinoscrotal masses such as hernia, lipoma, epididymal cyst, and incomplete resections of malignant masses which are thought to be benign, can lead to tumor recurrence in up to $50 \%$ of patients (4).

Paratesticular sarcomas are tumors with poor prognosis, originating from embryonic mesenchymal cells. The incidence of soft tissue sarcoma is 5 in 100.000 per year, of which less than $5 \%$ is due to the genitourinary system. It accounts for $1-2 \%$ of all genitourinary malignancies (4). Since paratesticular sarcoma is rare, studies with a large population of patients in the literature are very few $(5,6)$. Therefore, our knowledge of its natural course and prognosis is limited, and no definitive follow-up and treatment protocols have been established. To our knowledge, the largest patient series belong to Ap Dafydd et al. (4) whose study was performed on 77 patients.

Tumor stage, degree, histopathological subtype and size are important in predicting resectability and survival in paratesticular sarcomas $(5,6)$. Complete surgical resection, known to increase survival rates, is the recommended treatment to be done in the first stage. Adjuvant treatment protocols have not yet been standardized and their contribution to survival varies in different studies (6). Since our knowledge of paratesticular masses is limited, we aimed to examine the clinical-pathological characteristics of benign and malignant patients in our clinic and to evaluate the prognostic factors that may have an effect on oncological outcomes in cases with sarcoma.

\section{Methods}

We examined the pathological data of patients who underwent radical orchiectomy due to intratesticular or extratesticular mass in our clinic between January 2013 and February 2017. Nine patients with ages of 3-72 years who were treated and followed up due to paratesticular masses were included in the study. The clinical and histopathological data of the patients and their findings in postoperative follow-up were evaluated retrospectively. Demographic data, presenting symptoms, side of the tumor, localization of the tumor in the paratesticular area, the status of metastasis at diagnosis, pathological tissue diagnosis, pathological tumor size, the performed surgical treatments, surgical resection status (complete/incomplete), surgical margin positivity, adjuvant therapy given during postoperative followup, postoperative follow-up period, local recurrence, progression and survival status were recorded.

The French Fédération Nationale des Centers de Lutte Contre le Cancer (FNCLCC) Grading system was used for the pathological examination of patients with sarcoma and the pathological rating of each patient was recorded according to this system. In this system, three parameters including tumor differentiation, mitotic activity and tumor necrosis degree are scored separately and according to the total score, patients are classified as grades I, II, III (low, medium, high grade) in terms of sarcoma grade $(7,8)$.

\section{Statistical Analysis}

Before comparing the differences between benign and malignant pathologies, normality status was evaluated with KolmogorovSmirnov and Shapiro-Wilk tests. When there was normal distribution, Independent Sample t-test was used to compare age and tumor size, which are independent continuous variables. While Kaplan-Meier method was used for survival analysis in malignant patients, differences between patient subgroups were evaluated by the log rank test. This study was not suitable for the multivariate model, due to the small size of the sample. The analyses were done using IBM SPSS Statistics 21 (IBM, Armonk, NY USA) software. $\mathrm{P}<0.05$ was considered statistically significant. 


\section{Results}

The mean age at diagnosis of the nine male patients included in the study was $38.67 \pm 22.18$ years. Seven patients $(77.8 \%)$ were admitted with scrotal mass or swelling, while two patients (22.\%) were admitted with swelling in the inguinal area. Histological types of malignant tumors were rhabdomyosarcoma [(RMS), 2 cases, 22.3\%)], liposarcoma [(LPS), 1 case, 11.1\%)], leiomyosarcoma [(LMS), 1 case, 11.1\%)] and malignant fibrous histiostoma $[(\mathrm{MFH}), 1$ case, 11.1\%)]. Benign tumors were fibroma (1 case, 11.1\%), adenomatoid tumor (1 case, $11.1 \%$ ), cystadenoma (1 case, $11.1 \%$ ) and inflammatory myofibroblastic tumor (1 case, $11.1 \%)$. Since the suspicion of malignancy could not be ruled out clinically, surgical excision was applied in all patients. Surgical boundary positivity was observed in only one $(11.1 \%)$ of all patients undergoing complete resection. Preoperative serum tumor markers (alpha fetoprotein, beta human chorionic gonadotropin, lactate dehydrogenase) were normal in all patients.

No metastasis was detected at the time of diagnosis in any of the five patients with sarcoma. Neoadjuvant therapy was not applied to the patients; adjuvant chemotherapy (CT) was administered in three patients, adjuvant radiotherapy (RT) was administered in one case, and one case was followed up. The recurrence-free and progression-free survival rate was $60 \%$, while the overall

Table 1. Demographic, clinical, pathological data and oncological results of patients gender

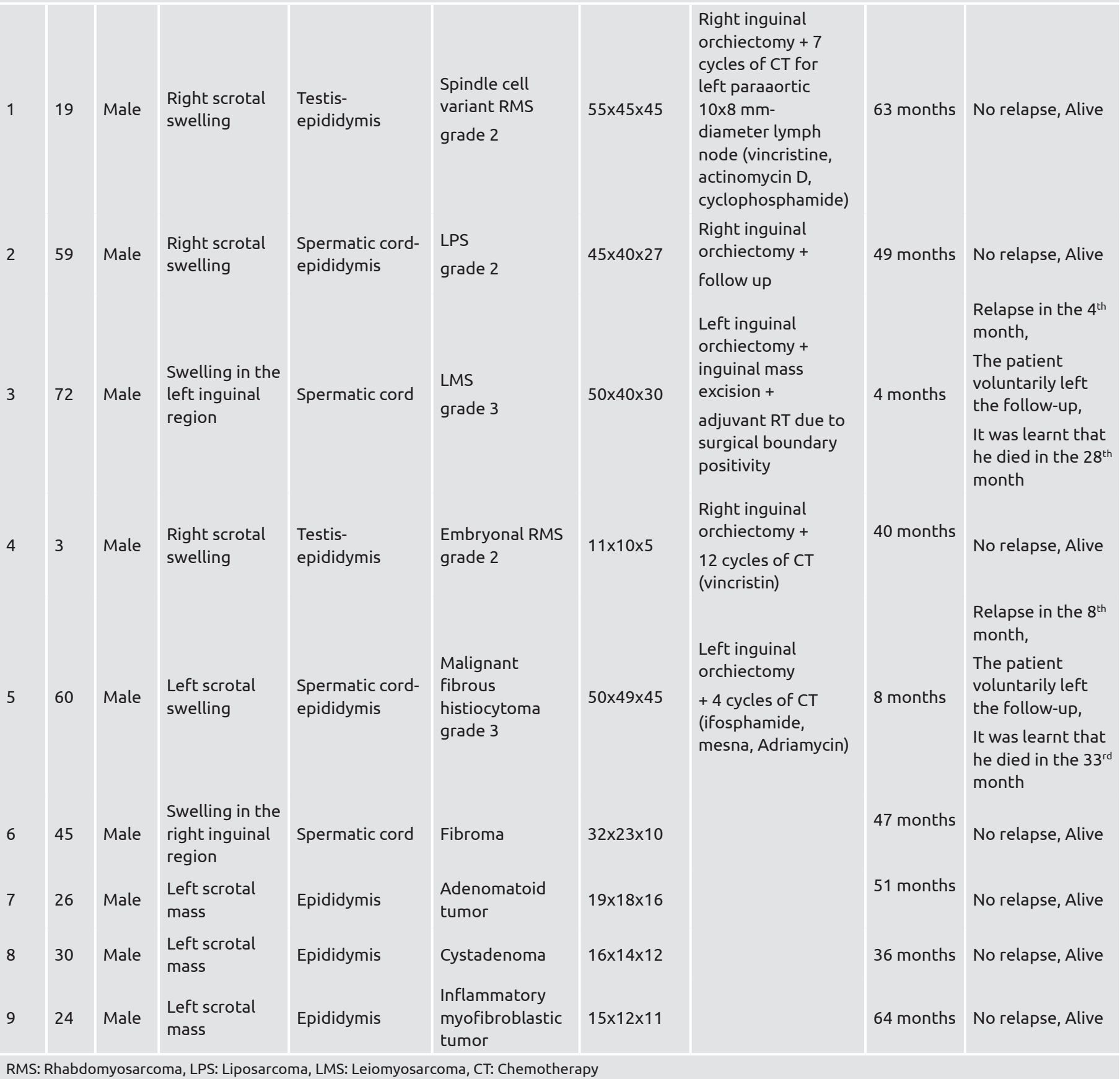


survival rate was $60 \%$ in 5 patients with sarcoma during a median 23.5-month follow-up (4-62 months). Among these cases, those with the worst prognosis were LMS and MFH. In the case with LMS, after radical orchiectomy, adjuvant RT was applied due to surgical boundary positivity, but in the early stage (in the $4^{\text {th }}$ month) there was local recurrence. In our case with MFH, local recurrence was detected in the $8^{\text {th }}$ month. We do not know about the state of progression in these patients due to lack of follow up. However, the overall survival times of these patients were 28 and 33 months, respectively. In the follow-up of patients with LPS and RMS, recurrence and progression were not observed. We determined LPS as the histopathological type with better prognosis, because that patient with LPS did not show recurrence and progression during 49 months of follow-up, even though we did not administer adjuvant therapy.

The disease-free survival rate was $100 \%$ during the median 49-month follow-up (36-64 months) of four patients with benign masses without need of adjuvant therapy. While the mean tumor size was $43.00 \pm 18.04 \mathrm{~mm}$ in patients with sarcoma, the tumor size in benign masses was significantly smaller $(20.25 \pm 8.09$ $\mathrm{mm})(\mathrm{p}=0.047)$. No significant difference was observed between benign and malignant patients in terms of mean age at diagnosis $(33.75 \pm 8.18$ and $42.60 \pm 29.83$, respectively) $(\mathrm{p}=0.555)$. The characteristics of the cases are seen in Table 1.

The oncological results of five patients with sarcoma were evaluated in terms of patient age, histopathological subtype of tumor, FNCLCC rating system and tumor size ( $>5$ or $<5 \mathrm{~cm}$ ). In Kaplan-Meier analysis, local survival time without recurrence and overall survival time were significantly higher in grade II sarcomas than in grade III sarcomas according to FNCLCC classification $(\mathrm{p}=0.039$, Figure 1,2$)$. No significant effects of other parameters were observed on survival without local recurrence and overall survival (Figure 3, 4, 5).

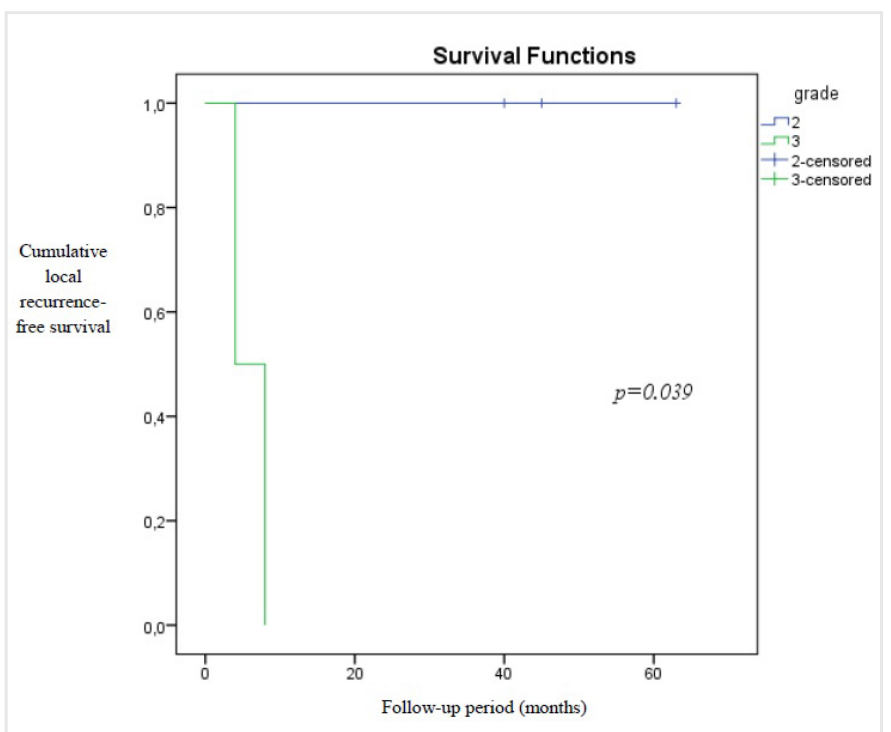

Figure 1. Kaplan-Meier graph of local recurrence-free survival curves according to histopathological grade

\section{Discussion}

It is known that there is a lower rate of malignancy in paratesticular masses than intratesticular masses (3). When we examined our patient data, we detected germ cell tumors in 75 (87.2\%) of 86 cases who underwent radical orchiectomy due to testicular mass in our clinic, while we observed malignancy in five $(55.5 \%)$ of nine paratesticular masses. The incidence of paratesticular sarcoma was reported as $6.7 \%$ in radical orchiectomies performed with suspicion of testicular tumor (9), whereas in our radical orchiectomy series, this rate was 5.2\%. Paratesticular benign tumors are more common in the third and fourth decades, while malignant tumors occur in the sixth and

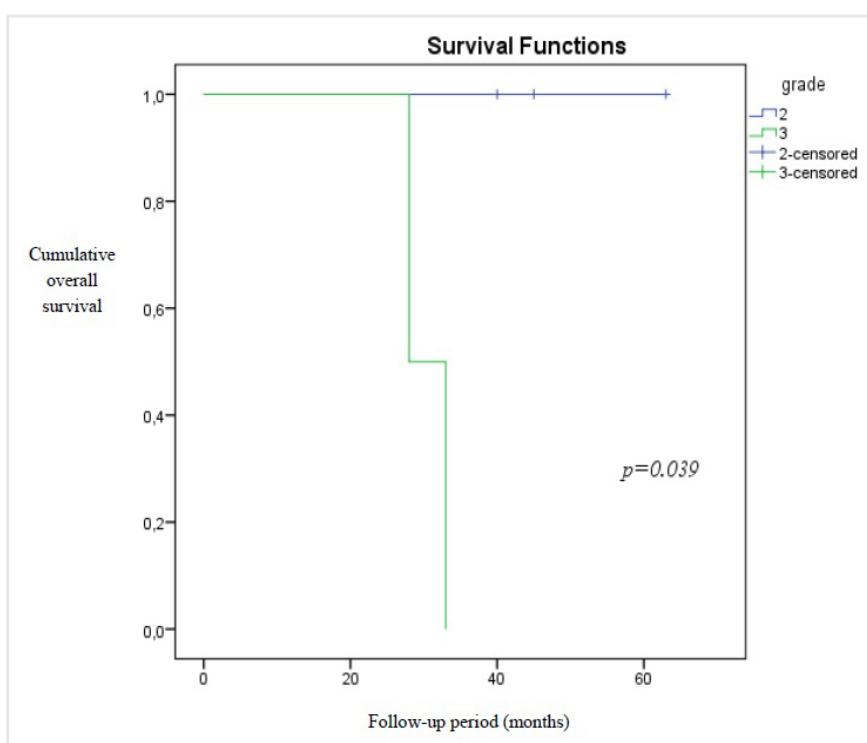

Figure 2. Kaplan-Meier graph of overall survival curves according to histopathological grade

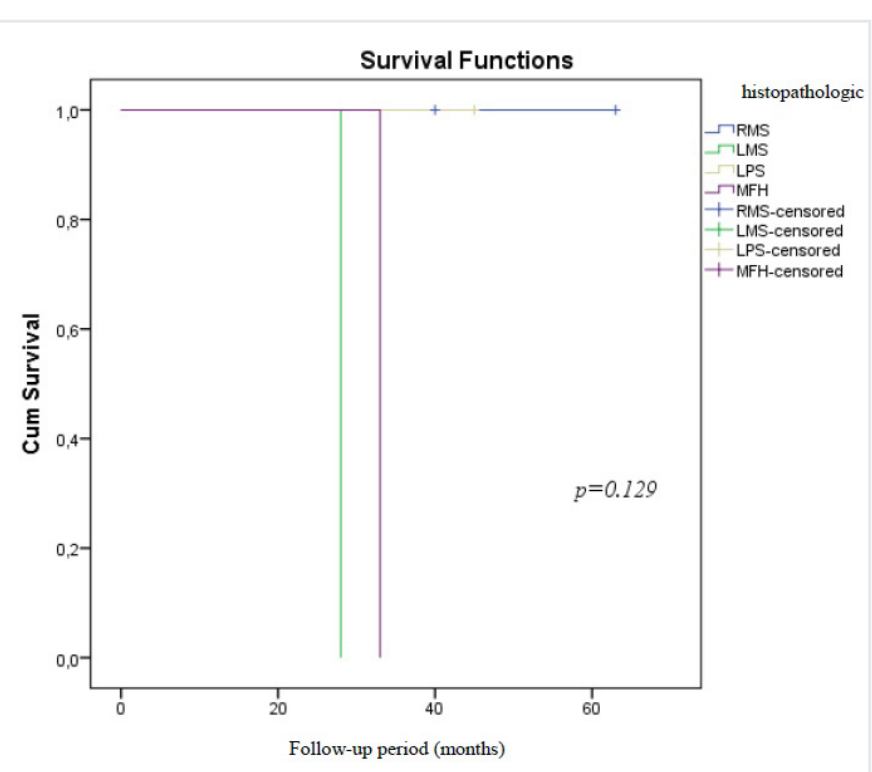

Kaplan-Meier survival graph according to histopathological tumor type

RMS: Rhabdomyosarcoma, LMS: Leiomyosarcoma, LPS: Liposarcoma, MFH: Malignant fibrous histiocytoma 
seventh decades (10). Similarly, the mean age at diagnosis was $33.75 \pm 8.18$ years in benign patients and $42.60 \pm 29.83$ years in malignant patients in our study.

Paratesticular masses constitute $2-3 \%$ of all scrotal masses, $30 \%$ of these masses are sarcomas, more than half are benign tumors (11). Adenomatoid tumors, the most common benign mesothelial tumors of the paratesticular region, constitute $30 \%$ of all paratesticular neoplasms and $60 \%$ of all benign neoplasms (12). The second most common benign tumor is cystadenoma. Both tumors originate mostly from the epididymis (13). Synonym names such as inflammatory pseudotumor, atypical myofibroblastic tumor, and pseudosarcomatous myofibroblastic proliferation are also used for inflammatory myofibroblastic tumors (IMT), which account for about $6 \%$ of paratesticular masses (14). While there were no reported relapses in follow-

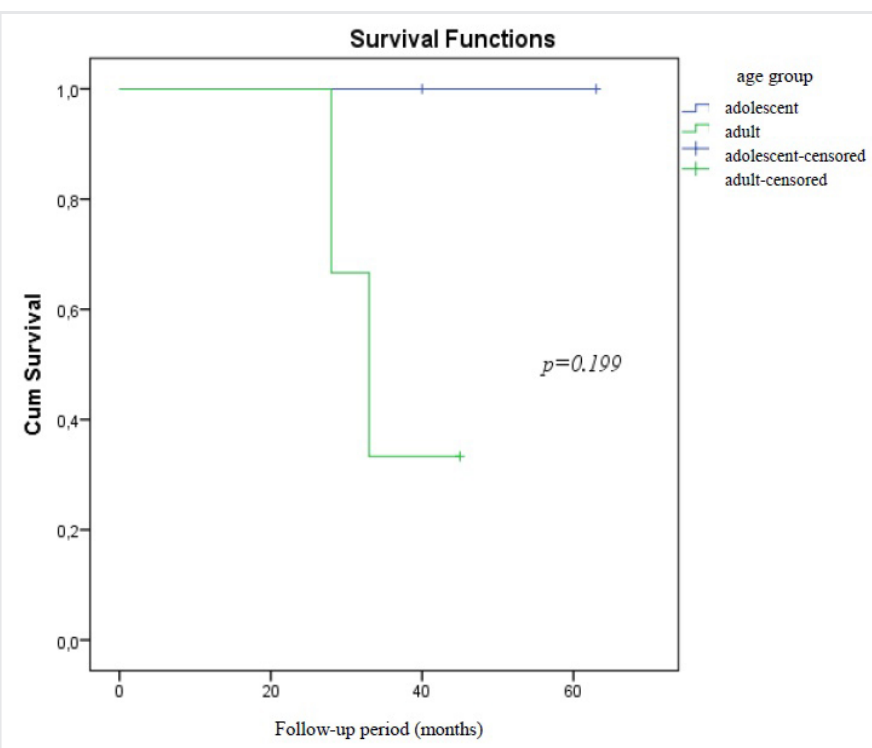

Figure 4. Kaplan-Meier survival graph according to patient age groups

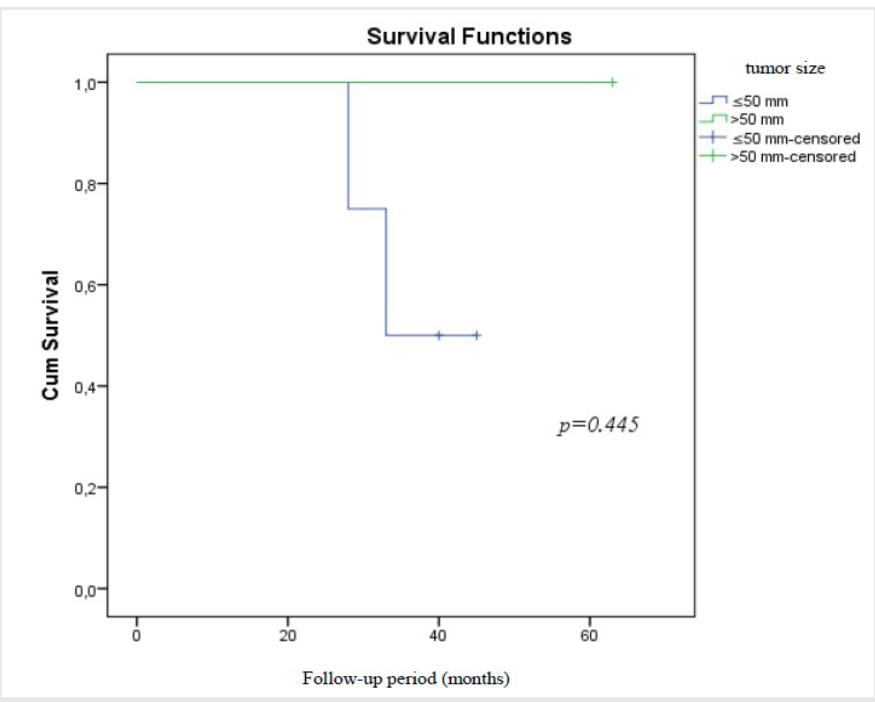

Figure 5. Kaplan-Meier survival graph according to tumor size up, distant metastasis was observed in less than $5 \%$ of nonepididymic IMT cases (15). Fibromas, which constitute $6 \%$ of paratesticular tumors, originate from tunica vaginalis in $75 \%$ of cases and from epididymis in $10 \%$ of cases, and spermatic cord involvement is much rarer (16).

Since benign tumors with paratesticular placement do not show recurrence and progression, total mass excision with using a testicular protective approach is sufficient treatment method (2). However, it is often difficult to distinguish malignancy with clinical examination and radiological methods. Radical orchiectomy may be preferred especially in patients with involvement of tunica albuginea, rete testis and spermatic cord (2).

Since our information on paratesticular sarcomas belongs to series with a limited number of patients published in the literature; there is still no consensus on optimal treatment regimens and follow-up protocols $(17,18)$. The most common type among all soft tissue sarcomas is LPS, while the most common types among genitourinary-derived sarcomas are LMS (29\%), LPS (26\%) and RMS (18\%) (6), respectively. The most common types among paratesticular sarcomas are LPS (20-32\%), LMS (19-32\%) and RMS (11-24\%) (19). We observed RMS in two cases $(40 \%)$, LPS in one case (20\%), LMS in one case $(20 \%)$ and $\mathrm{MFH}$ in one case $(20 \%)$ in patients with paratesticular sarcomas. However, because we have few cases, our rates do not match the literature. Embryonal type RMS is the most common paratesticular sarcoma in children and adolescents (19) and our 3-year and 19-year-old patients with RMS are compatible with the literature in this respect.

The admission complaint in paratesticular sarcomas is mostly painless scrotal mass and they develop from the mesenchymal elements of the spermatic cord, epididymis and testicular sheath. About $70 \%$ of them settle on spermatic cord (10). Of the five patients with sarcoma in our study, three $(60 \%)$ originated from the spermatic cord.

When all genitourinary sarcomas are examined in the literature, survival rates of paratesticular sarcomas and sarcomas originating from bladder are reported to be higher than those originating from other organs (6). This was attributed to early admission of patients due to scrotal swelling in paratesticular sarcoma and hematuria in bladder sarcoma and to diagnosis in earlier stages (5). All nine cases in our study were admitted with noticeable swelling in the scrotal or inguinal region, and none of the five patients diagnosed as having sarcoma had metastasis at the time of diagnosis.

RMS is the most common primary paratesticular malignant neoplasia between 7 and 36 years of age (average age at diagnosis is 10 years) (20). It accounts for $80 \%$ of paratesticular tumors seen under the age of 21 and $24 \%$ of those detected in adults (21). The histopathological types; "embryonal type" and "spindle cell variant", found in two cases with paratesticular RMS in our study had a better prognosis than the other RMS subtypes (22). In fact, no recurrence and progression were observed in the mean 50.5-month (39-62 months) follow-up of both cases. 
There are fewer reported cases with paratesticular LMS and LPS in the literature $(23,24)$. Fisher et al. (23) showed that development of recurrence and metastasis can be prevented with radical orchiectomy in patients with low-grade paratesticular LMS. In our case, surgical boundary positivity was observed after complete excision and he received adjuvant RT. Despite multimodal treatment, development of local recurrence in the $4^{\text {th }}$ month could not be prevented. Paratesticular LPS is mostly well differentiated and expected survival is longer in patients with paratesticular LPS $(24,25)$. In our case with grade II paratesticular LPS, no recurrence or progression were observed during 48-month follow-up without adjuvant treatment.

There is still debate about the role of retroperitoneal lymphadenectomy (RPLND) in paratesticular sarcomas (2527). At the time of diagnosis, only CT was applied instead of RPLND as adjuvant treatment for our RMS patient with a 10x8 $\mathrm{mm}$ diameter lymph node with a $10 \times 8 \mathrm{~mm}$ diameter lymph node in the left paraaortic area. No recurrence or progression was observed during 62 months of follow-up.

The frequency of MFH, which is very rare and fast progressive, is $4.5 \%$ in all genitourinary sarcomas and $11.1 \%$ in paratesticular sarcomas (5). The size and histopathological characteristics of the tumor are important factors for development of metastasis. Despite multimodal treatment, 3-year survival is approximately $40 \%$ (28). The overall survival was 33 months in our patient with grade III paratesticular MFH. Despite adjuvant CT, he developed local recurrence in the $8^{\text {th }}$ month.

There are very few reported studies regarding long-term followup results of paratesticular sarcomas. Since there is a greater incidence of RMS in the pediatric age group, most of the survival results were obtained from multicenter publications of RMS cases (9). Korkes et al. (9) indicated that overall survival was $27.8 \pm 6.2$ months and overall survival rate was $50 \%$ after a median 31.4 (6-60) months of follow-up. In the same study, lung metastasis was observed in 50\% of cases with LMS, while recurrence or progression was not detected in cases with LPS, and metastasis rate in RMS was found to be $50 \%$. They found no difference between sarcoma types in terms of disease-free survival (9). In another study with a median 32.18 months (1-142) of follow-up, overall survival rate was $12.5 \%$ (29). Dotan et al. (6) showed that increased tumor size, incomplete surgical resection, positive surgical boundary and metastasis at the time of diagnosis in all genitourinary sarcomas were identified as negative factors that reduce disease-specific survival. Although the 5-year local recurrence rate was reported as $32 \%$, metastasis-free survival rate as $60 \%$ and disease-specific survival rate as $69 \%$; no subgroup analysis was performed for paratesticular sarcomas in this study (6).

Having the largest known series of patients (188 patients) with all kinds of genitourinary sarcomas, Dotan et al. (6) showed that 5 -year disease-free survival rate was $12.5 \%$ and cancerspecific survival was $25 \%$. in subgroup analyses of 56 patients with paratesticular sarcoma. The negative factors that affect srecurrence-free survival are renal placement, female gender, presence of metastases at diagnosis, and positive surgical margin and the negative factors that affect metastasis-free survival are the presence of incomplete surgical resection and positive surgical margin. During a median 23.5 (4-62) months of follow-up, we observed recurrence-free and progression-free survival as $60 \%$ and overall survival as $60 \%$ in five patients with sarcoma. In addition, we found local recurrence-free survival time and overall survival time were significantly higher in grade II sarcomas than in grade III sarcomas according to FNCLCC classification, while we were unable to show any significant effect of other parameters on oncological outcomes.

While complete surgical excision is the recommended treatment in the first step, the location of adjuvant CT and RT is still unclear. Although adjuvant treatments have been reported to reduce local recurrence and extend overall survival $(9,30)$, in two cases with grade III tumor in our study, recurrence and progression were observed in a short period of time despite adjuvant CT and/or RT.

\section{Study Limitations}

The retrospective design of our study, the inability to create randomization, the limited statistical analysis due to the small number of patients, short follow-up times and the follow-up results belonging to one center are the main limitations of our study.

\section{Conclusion}

As a result, paratesticular masses are rare and low malignant pathologies, but it is often difficult to distinguish them with clinical findings. In cases where the suspicion of malignancy cannot be ruled out, radical orchiectomy is inevitable. In sarcomas of this region, complete surgical excision is often not sufficient for disease-free survival. Adjuvant treatments, on the other hand, do not increase overall survival in every case. According to our findings, tumor grade is the most important prognostic factor determining relapse and overall survival. It is necessary to better identify the prognostic factors that have effect on survival and to establish specific adjuvant treatment protocols according to the tumor subtype with other prospective, randomized, controlled, multicenter with large patient numbers and long follow-up.

\section{Ethics}

Ethics Committee Approval: Association Declaration of Helsinki "Ethical Principles for Medical Research Involving Human Subjects", (amended in October 2013).

Informed Consent: A consent form was completed by all participants.

Peer-review: Externaly peer-reviewed.

\section{Authorship Contributions}

Concept: İ.S., Design: İ.S., Data Collection or Processing: İ.S., Analysis or Interpretation: İ.S., H.B., Literature Search: İ.S., Writing: İ.S.

Conflict of Interest: No conflict of interest was declared by the authors. 
Financial Disclosure: The authors declared that this study received no financial support.

\section{References}

1. Lioe TF, Biggart JD. Tumours of the spermatic cord and paratesticular tissue. A clinicopathological study. Br J Urol 1993;71:600-6.

2. Behzatoğlu K, Boyacı C, Sığırcı BB. Paratesticular Tumors and Clinicopathologic Approach. Bulletin of Urooncology 2015;14:2717.

3. Unlü Y, Huq GE, Ozyalvaçli G, Zengin M, Koca SB, Yücetas U, et al. Paratesticular sarcomas: A report of seven cases. Oncol Lett 2015;9:308-12.

4. Ap Dafydd D, Messiou C, Thway K, Strauss DC, Nicol DL, Moskovic E.Paratesticular Sarcoma: Typical Presentation, Imaging Features, and Clinical Challenges. Urology 2017;100:163-8.

5. Mondainia N, Pallib D, Saieva C, Nesi G, Franchi A, Ponchietti R, et al. Clinical Characteristics and Overall Survival in Genitourinary SarcomasTreated with Curative Intent: A Multicenter Study. European Urology 2005;47:468-73.

6. Dotan ZA, Tal R, Golijanin D, Snyder ME, Antonescu C, Brennan MF, et al. Adult Genitourinary Sarcoma: The 25-Year Memorial Sloan-Kettering Experience. J Urol 2006;176:2033-9.

7. Coindre JM, Terrier P, Bui NB, Bonichon F, Collin F, Le Doussal V, et al. Prognostic factors in adult patients with locally controlled soft tissue sarcoma. A study of 546 patients from the French Federation of Cancer Centers Sarcoma Group. J Clin Oncol 1996;14:869-77.

8. Coindre JM, Trojani M, Contesso G, David M, Rouesse J, Bui NB, et al. Reproducibility of a histopatological grading system for adult soft tissue sarcoma. Cancer 1986;58:306-9.

9. Korkes F, Castro MG, Romero FR, Godoy G, Amary MF, Fernandes RC et al. Paratesticular sarcomas in Brazil. Urol Int 2009;82:448-52.

10. Akbar SA, Sayyed TA, Jafri SZ, Hasteh F, Neill JS. Multimodality imaging of paratesticular neoplasms and their rare mimics. Radiographics 2003;23:1461-76.

11. Russo P, Brady MS, Colon K, Hajdu SI, Fair WR, Herr HW, et al. Adult Urological Sarcoma. J Urol 1992;147:1032-7.

12. Kontos S, Fokitis I, Karakosta A, Koritsiadis G, Mitsios K, Koutsikos $S$, et al. Adenomatoid tumor of epididymis: a case report. Cases Journal 2008;206-9.

13. Gokce G, Kilicarslan H, Ayan S, Yildiz E, Kaya K, Gultekin EY. Adenomatoid tumors of testis and epididymis: a report of two cases. Int Urol Nephrol 2001;32:677-80.

14. Tunuguntla H, Mishra A, Jorda M, Gosalbez R. Inflammatory myofibroblastic tumor of the epididymis: case report and review of the literature. Urology 2011;78:183-5.

15. Fletcher CDM, Unni KK, Mertens F. Inflammatory myofibroblastic tumor. In: Fletcher CDM, Unni KK, Mertens F, editors. World Health Organization classification of tumours: pathology and genetics of tumours of soft tissue and bone. Lyon: IARC Press; 2002. P.91-93.

16. Woodward PJ, Schwab CM, Sesterhenn IA. From the archives of the AFIP: extratesticular scrotal masses: radiologic-pathologic correlation. Radiographics 2003;23:215-40.

17. Lee G, Lee SY, Seo S, Jeon S, Lee H, Choi H, et al. Prognostic factors and clinical outcomes of urological soft tissue sarcomas. Korean J Urol 2011;52:669-73.

18. Vuruskan BA, Ozsen M, Coskun B, Yalcinkaya U. Evaluation of incidence and histolopathological findings of soft tissue sarcomas in genitourinary tract: Uludag university experience. Int Braz J Urol 2019;45:68-73.

19. Khoubehi B, Mishra V, Ali M, Motiwala H, Karim O, et al. Adult paratesticular tumours. BJU Int 2002;90:707-15.

20. Ferrari A, Bisogno G, Casanova M, Meazza C, Piva L, Cecchetto G, et al. Paratesticular rhabdomyosarcoma: report from the Italian and German Cooperative Group. J Clin Oncol 2002;20:449-55.

21. Stevens MC, Rey A, Bouvet N, Ellershaw C, Flamant F, Habrand JL, et al. Treatment of nonmetastatic rhabdomyosarcoma in childhood and adolescence: third study of the International Society of Paediatric Oncology- SIOP Malignant Mesenchymal Tumor 89. J Clin Oncol 2005;23:2618-28.

22. Sinha NK. Paratesticular rhabdomyosarcoma in young adult- a case report. J Clin Diagn Res 2015;9:ED01-2.

23. Fisher C, Goldblum JR, Epstein JI, Montgomery E. Leiomyosarcoma of the paratesticular region: a clinicopathologic study. Am J Surg Pathol 2001;25:1143-9.

24. Montgomery E, Fisher C. Paratesticular liposarcoma: a clinicopathologic study. Am J Surg Pathol 2003;27:40-7.

25. Cho SY, Moon KC, Cheong MS, Kwak C, Kim HH, Ku JH. Localized Resectable Genitourinary Sarcoma in Adult Korean Patients: Experiences at a Single Center. Yonsei Med J 2011;52:7617.

26. Catton CN, Cummings BJ, Fornasier V, O'Sullivan B, Quirt I, Warr D. Adult paratesticular sarcomas: a review of 21 cases. J Urol 1991;146:342-5.

27. Hermans BP, Foster RS, Bihrle R, Little S, Sandler A, Einhorn LH, et al. Is retroperitoneal lymph node dissection necessary for adult paratesticular rhabdomyosarcoma? J Urol 1998;160:2074-7.

28. Celik O, Turk H, Budak S, Ilbey YO. Rare type of bladder cancer: malign fibrous histiocytoma. Arch Ital Urol Androl 2014;86:158-9.

29. Pérez JC, Licham MA, Godoy MP, Urrutia VD, Lihon JS. Adult paratesticular sarcomas. Management and evolution of the disease. Actas Urol Esp 2009;33:639-45.

30. Italiano A, Delva F, Mathoulin-Pelissier S, Le Cesne A, Bonvalot $S$, Terrier P, et al. Effect of adjuvant chemotherapy on survival in FNCLCC grade 3 soft tissue sarcomas: a multivariate analysis of the French Sarcoma Group Database. Ann Oncol 2010;21:2436-41. 